\title{
DELEUZE, LEITOR DE ESPINOSA: AUTOMATISMO ESPIRITUAL E FASCISMO NO CINEMA
}

\author{
Susana Viegas* \\ susanarainhoviegas@gmail.com
}

RESUMO Neste texto, procuro encontrar as origens de um dos mais importantes conceitos de Gilles Deleuze, o conceito de Imagem-tempo. Este conceito remete-nos para os primeiros textos de Deleuze dedicados à filosofia de Espinosa e ao problema do autómato espiritual e relaciona-se directamente com o problema da passividade/actividade do espectador. Ou seja, o conceito crucial na sua filosofia do cinema, a Imagem-tempo, esconde uma importante reflexão sobre a Imagem cinematográfica como arte de massas, os (im)poderes do pensamento e o modo fascista de se pensar.

Palavras-chave: Deleuze, Espinosa, Filosofia do cinema, Automatismo espiritual.

ABSTRACT This text seeks to find the origins of one of the most important Gilles Deleuze's concept, the concept of Time-image. This concept leads us to his first texts regarding Spinoza's philosophy and the problem of the spiritual automaton and concerns directly with the problem of passivity/activity of the film goer. That is to say that the crucial concept of his film philosophy, the Time-image, hides a fundamental consideration on the cinematic image as a mass art, the (un)powers of thinking and the fascist way of thought.

Keywords: Deleuze, Spinoza, Film Philosophy, Spiritual Automatism. 
Le vieux fascisme si actuel et puissant qu'il soit dans beaucoup de pays, n'est pas le nouveau problème actuel. On nous prépare d'autres fascismes.

$(\text { Gilles Deleuze) })^{1}$

\section{Introdução: Espinosa, segundo Deleuze}

As leituras que Gilles Deleuze faz, breves no caso do pensamento de Heidegger, mais extensas no caso do pensamento de Kant, Nietzsche ou de Bergson, correspondem a um longo e complexo tecer de ideias que tem como principal objectivo a procura de um pensamento da diferença, isto é, da possibilidade de encontrar outras modalidades para se pensar a diferença em relação ao começo filosófico e à estética (teoria do sensível). É precisamente neste tecido de ideias que Espinosa se torna num filósofo crucial; para além de ser uma influência directa na filosofia deleuziana, Deleuze cria ainda um encontro original entre o "poder do pensamento" em Espinosa e o "poder do falso" em Nietzsche: esse encontro tornar-se-á explícito com a criação do conceito de "Imagem-tempo" nos anos 1980.2 "O movimento automático" defendido em "A Imagem-tempo", "faz surgir em nós um autômato espiritual, que, por sua vez, reage sobre ele." "3 Do ponto de vista teórico, a associação entre o automatismo do mecanismo cinematográfico e os processos mentais dos espectadores remonta às primeiras teorias sobre o cinema. Em 1937, Faure faz um dos primeiros elogios ao cinema, ao aproximar o "automatismo material", próprio da técnica cinematográfica, ao "automatismo intelectual" do espectador:

Na verdade, é o seu próprio automatismo material que faz surgir do interior destas imagens este novo universo que impõe pouco a pouco ao nosso automatismo intelectual. É deste modo, que aparece numa luz ofuscante, a subordinação da alma humana aos instrumentos que ela cria e vice-versa. Entre tecnicidade e afectividade, surge uma reversibilidade constante. ${ }^{4}$

Epstein defendia a especificidade da "máquina de pensar" que é o cinema: o cinematógrafo foi, gradualmente, criando um "cérebro mecânico", directa

1 Deleuze, 2003b, p. 125, pequeno texto de 1977 no qual Deleuze analisa a censura e interdição em França do filme "Schatten der Engel" (1975), de Daniel Schmid.

2 Deleuze, 1983 (Deleuze, 2009) e Deleuze, 1985 (Deleuze, 2005).

3 Deleuze, 1985, p. 203 (Deleuze, 2005, p. 189, itálico no original): "Le mouvement automatique fait lever en nous en automate spirituel, qui réagit à son tour sur lui."

4 Faure, 1964, p. 56: "En vérité, c'est son automatisme matériel même qui fait surgir de l'intérieur de ces images ce nouvel univers qu'il impose peu à peu à notre automatisme intellectuel. C'est ainsi qu'apparaît, dans une lumière aveuglante, la subordination de l'âme humaine aux outils qu'elle crée, et réciproquement. Entre technicité et affectivité, une réversibilité constante s'avère." 
e indirectamente relacionado com a própria inteligência humana e que, no fundo, conduziu à criação de uma "filosofia de um cérebro-robot que não foi intencional e estritamente regulado para realizar um trabalho idêntico ao do órgão vivo". ${ }^{5}$ Porém, a interpretação que Deleuze faz dessa associação entre a técnica cinematográfica e a mente do espectador é inovadora no próprio recurso que faz do conceito de "autómato espiritual", conceito que é, em primeiro lugar, uma leitura de Espinosa, mas também de Leibniz. Mas, se o conceito de autómato espiritual nos remete para aquilo que na tradição filosófica diz respeito à unidade entre mente e corpo, ele surge aqui deslocado, de alguma forma actualizado pelo cinema e significando, por sua vez, e primeiramente, o circuito criado pelo choque entre a Imagem-movimento e o pensamento. Assim, na filosofia do cinema de Deleuze, o autómato espiritual ou mental já não designa, como na filosofia de Espinosa, a possibilidade lógica de um pensamento que deduziria as ideias umas das outras, ou seja, a dedução de um pensamento mediante um outro pensamento.

O Método não é outra coisa senão o conhecimento reflexivo ou a ideia da ideia; e porque não há a ideia da ideia se não existir primeiramente a ideia, portanto, não há Método a não ser que haja primeiramente a ideia. Por consequência, será bom aquele Método que mostre como a mente deve ser dirigida pela norma de dada ideia verdadeira. ${ }^{6}$

\section{Espinosa, o autómato e a autonomia espiritual}

Em Espinosa, o conceito de autómato espiritual surge, pela primeira e única vez, ${ }^{7}$ numa obra póstuma e inacabada, "Tratado sobre a Reforma do Entendimento". Este livro divide-se em duas partes: uma primeira sobre o objectivo do método, do pensamento, sobre a "forma da ideia verdadeira"; e uma segunda sobre o "conteúdo da ideia verdadeira ou adequada", isto é, sobre o modo de concretizar o primeiro objectivo. Iniciando o livro naturalmente pela dúvida, Espinosa começa por nos indicar que o "autómato" corresponde ao Homem do cepticismo "cego", radical, ou seja, ao sujeito cartesiano que afirma e duvida sem que, no entanto, tenha conhecimento de que é ele quem

5 Epstein, 1946, p. 186: “[...] philosophie d'un cerveau-robot qui n'a pas été intentionnellement et strictement réglé pour accomplir un travail identique à celui de l'organe vivant."

6 Espinosa, 1964, p. 192 (Espinosa, 1971, p. 44): "La méthode n'est pas autre chose que la connaissance réflexive ou l'idée de l'idée ; et, n'y ayant pas d'idée d'une idée, si l'idée n'est pas donnée d'abord, il n'y aura donc point de méthode si une idée n'est donnée d'abord. La bonne méthode est donc celle qui montre comment l'esprit doit être dirigé selon la norme de l'idée vraie donnée."

7 Coadou, 2002, p. 187. 
afirma e duvida: "Se negam, concedem ou opõem, não sabem que negam, concedem ou opõem e, portanto, têm de ser considerados como autómatos totalmente privados de pensamento". 8

Numa primeira acepção do termo, "autómato" designará a privação de pensamento, a inexistência de espírito, ou a falta de espírito reflexivo naqueles que não sabem sequer que duvidam quando afirmam duvidar - ou, em termos cartesianos, não se compreendem como Cogito. Entretanto, de acordo com Deleuze, o dualismo cartesiano tinha impedido a criação da personagem conceptual do "autómato espiritual", enquanto unidade de alma e corpo numa identidade indivisivel entre forma e matéria. Ora, o conceito de autómato espiritual é justamente abandonado na Ética e substituído pelo conceito de conatus aliando, desse modo, o autómato espiritual com o "autómato corporal". 9

A superação desse dualismo será uma das razões do interesse pelo pensamento de Espinosa, uma vez que, se, numa primeira parte, a exposição do método reflexivo ("ideia da ideia" ou o poder de pensar) não nos dá a conhecer mais do que o poder que temos em conhecer, numa segunda parte, Espinosa desenvolve a questão da ideia adequada ou o conteúdo da ideia verdadeira, seja enquanto reflexiva, como na ideia da ideia, seja enquanto expressiva, como na ideia adequada. ${ }^{10}$

Pensar é, segundo esta definição, seguir as leis do pensamento, as leis que determinam a forma e o conteúdo das ideias verdadeiras:

Ao pensarmos, não obedecemos senão às leis do pensamento, leis que determinam ao mesmo tempo a forma e o conteúdo da ideia verdadeira, que nos fazem ligar as ideias a partir das suas próprias causas e de acordo com o nosso próprio poder, ainda que não conheçamos o nosso poder de compreender sem conhecer pelas causas todas as coisas que caiem sob este poder. ${ }^{11}$

8 Espinosa, 1964, p. 195 (Espinosa, 1971, p. 50, ligeiramente modificado): "S'ils nient, concèdent, ou opposent une objection, ils ne savent qu'ils nient, concèdent ou opposent une objection; il faut donc les considérer comme des automates entièrement privés de pensée." Deleuze, porém, cita outra tradução de Espinosa feita por Ferdinand Alquié em que "privés de pensée" surge como "dépourvus d'esprit" (versão essa que, por seu lado, está na base da tradução portuguesa "carecem totalmente de espírito", feita por António Borges Coelho).

9 Coadou, 2002, p. 194.

10 Deleuze, 1968, p. 117. Concatenatio enquanto encadeamento automático das ideias na ideia adequada.

11 Ibidem, p. 126: "En pensant nous n'obéissons qu'aux lois de la pensée, lois qui déterminent à la fois la forme et le contenu de l'idée vraie, qui nous font enchaîner les idées d'après leurs propres causes et suivant notre propre puissance, si bien que nous ne connaissons pas notre puissance de comprendre sans connaître par les causes toutes les choses qui tombent sous cette puissance." 
O que o método nos permite conhecer é o nosso poder de conhecer, o nosso poder de pensar, ${ }^{12}$ noção que, por seu lado, será a causa de todas as outras ideias que se lhe seguirão (de um modo automático). Segundo Espinosa, o autómato espiritual corresponde a um espírito que age de acordo com as leis determinadas. ${ }^{13}$ Ou seja, numa segunda acepção do termo, o "autómato" surge no texto de Espinosa como sinónimo de autonomia: a autonomia e a espontaneidade do pensamento. ${ }^{14}$ Numa nota de "Espinosa e o problema da expressão", Gilles Deleuze afirma justamente: "Apesar da diferença das duas interpretações, o autómato espiritual tem um aspecto comum em Leibniz e em Espinosa: ele designa a nova forma lógica da ideia, o novo conteúdo expressivo da ideia e a unidade desta forma e deste conteúdo". ${ }^{15}$

Conceito que surge directamente ligado a uma prévia noção de imanência (desenvolvida na "Ética"), o autómato espiritual é, por excelência, a Imagem do sujeito espinosano autoprodutivo: ou seja, "[a] noção espinosana de autômato espiritual possui profundas implicações de ordem ontológica, pois este, ao desdobrar-se, é o real que se afirma e se determina como tal". ${ }^{16} \mathrm{O}$ autómato espiritual é, portanto, uma unidade temporal indivisível do múltiplo, entre o modo de pensamento (intelecto como alma ou espírito) ${ }^{17}$ e o modo de extensão (corpo) de tal modo que, de uma forma reversível (de dobra ontológica), o espírito é expressão intelectual do corpo tal como o corpo é expressão extensa, espacial do espírito (paralelismo dos atributos na "Ética"). Ainda que este conceito tenha um tão grande destaque no livro de Deleuze dedicado a Espinosa, trata-se de um conceito inexistente na filosofia de Espinosa. ${ }^{18}$ Porém, na leitura deleuziana que seguimos, é o conceito de expressão que realiza a ligação Ser-Pensar: "São os conceitos espinosistas de substância e de

12 Temos o poder de pensar porque participamos no poder absoluto de pensar (Deus) (Deleuze, 1968, p. 124). Na sequência desta leitura deleuziana, compreendemos melhor o paradoxo do "privilégio do atributo pensamento" (Ibidem, p. 109 et seq.) na filosofia de Espinosa: ver, por exemplo, De Gainza, 2007, p. 77: "Um ser que pode pensar uma infinidade de coisas numa infinidade de modos é, então, necessariamente infinito pela virtude de pensar; quer dizer, um ser que tem uma potência absoluta de pensar tem necessariamente um atributo infinito que é o pensamento, condição necessária da possibilidade de todo e qualquer pensamento." Para além disso, para Deleuze, pensamos filosoficamente por conceitos mas também pensamos não-filosoficamente por afetos e percetos - é, justamente, o movimento entre os três que elabora o estilo da Ética (Deleuze, 2003c, p. 222).

13 Espinosa, 1964, p. 210.

14 Deleuze, 1968, p. 116.

15 Ibidem, p. 126: "Malgré la différence des deux interprétations, l'automate spirituel a un aspect commun chez Leibniz et chez Spinoza : il désigne la nouvelle forme logique de l'idée, le nouveau contenu expressif de l'idée, et l'unité de cette forme et de ce contenu."

16 Ezcurdia, 2001, p. 27.

17 Anima (alma) é o termo usado no "Traité de la réforme" ao passo que em "Étique" Espinosa adopta o termo mens (mente). Indicação presente nas notas finais de Espinosa, 1954, p. 1402.

18 Segundo Pierre Macherey, a palavra "expressio" não surge na "Ética"; aí apenas encontramos as várias formas do verbo "exprimere". Cf. Macherey, 1996, p. 144. 
modos que se relacionam com o plano de imanência como seu pressuposto. Este plano oferece-nos as suas duas faces, a extensão e o pensamento, ou, mais exactamente, os seus dois poderes, poder de ser e poder de pensar". ${ }^{19}$

Segundo Espinosa, tudo é causado pelo poder do pensamento, isto é, as ideias são a causa de outras ideias, sem que haja propriamente a concepção de um "Eu" que pense enquanto res cogitans; quem pensa é um agenciamento maquínico, como um autómato espiritual que pensa em nós. Neste sentido, pensar é obedecer às regras do pensamento, às leis que determinam a forma e o conteúdo das ideias verdadeiras que criam outras ideias unicamente pelo poder de pensar. Ou seja, a alma será unidade deste processo unicamente enquanto autómato espiritual.

\section{Automatismo, acção e reacção}

Ora, se Espinosa destaca o poder do pensamento, Deleuze vai contudo relacionar este poder com as ideias de Nietzsche e Artaud, pensadores que fazem a ruptura com um modo tradicional de pensar: afinal, perante a impotência em se pensar a verdade, qual é o valor do pensamento?

A questão da impotência do pensamento não diz apenas respeito à nossa relação com o cinema mas é, neste caso concreto, tanto o objecto do cinema quanto o seu sujeito. Para Deleuze, o maior poder que o pensamento pode expressar não está no modelo representativo, enquanto modelo do reconhecimento mas no pensamento do impensável, quando este enfrenta a sua maior impotência. Deleuze passa da questão do próprio mecanismo cinematográfico, um aparelho que faz mover as imagens, para as imagens que se automovem: o movimento é o dado imediato das imagens. Porém, o que lhe interessa nesta Imagem automática é a questão do pensamento: quando o movimento é automático. O autómato espiritual não é considerado apenas no sentido da filosofia clássica já analisado; o cinema torna-se no modelo do próprio funcionamento do pensamento e não num sucedâneo deste pois, como defende Deleuze, a essência do cinema é "produzir um choque no pensamento, comunicar vibrações ao córtex, tocar diretamente o sistema nervoso e cerebral". ${ }^{20}$

19 Deleuze e Guattari, 2005, p. 50 (Deleuze e Guattari, 1992, p. 47): “Ce sont les concepts spinozistes de substance et de modes qui se rapportent au plan d'immanence comme à leur présupposé. Ce plan nous tend ses deux faces, l'étendue et la pensée, ou plus exactement ses deux puissances, puissance d'être et puissance de penser."

20 Deleuze, 1985, p. 203 (Deleuze, 2005, p. 189, itálico no original): "Produire un choc sur la pensée, communiquer au cortex des vibrations, toucher directement le système nerveux et cérébral." 
Segundo a noologia defenida por Deleuze, "[a] teoria do pensamento é como a pintura: tem necessidade dessa revolução que faz com que ela passe da representação à arte abstracta; é este o objecto de uma teoria do pensamento sem imagem". ${ }^{21}$ A Imagem é compreendida como uma figura ou uma representação a eliminar. Deleuze, em "Diferença e Repetição", usa o termo “imagem" para a aproximar mais da noção de cliché, entendido como uma Imagem que pensa por nós segundo o senso comum não-filosófico. Isto é, ele usa o termo "imagem" no sentido de "representação" do pensamento: consequentemente, um pensamento sem Imagem equivalerá a um modo de pensar sem o modelo da representação e do reconhecimento. Pelo contrário, uma nova Imagem assinalará um tipo de pensamento não-representativo que renuncia à "forma da representação" e ao "elemento do senso comum". ${ }^{22}$ Em suma: "para um pensamento sem imagem" vem a significar para um pensamento sem representação enquanto destruição do Ícone, tal como acontece na ruptura que a arte abstracta faz na arte representativa. Ou seja, com a crítica radical,

Ela [a filosofia] encontraria a sua diferença ou o seu verdadeiro começo não num acordo com a Imagem pré-filosófica, mas numa luta rigorosa contra a Imagem, denunciada como não-filosofia. Ela encontraria assim, a sua repetição autêntica num pensamento sem Imagem. (grifos no original) ${ }^{23}$

Um pensamento sem Imagem diz respeito a um começo sem pressupostos, não seguindo a Imagem tradicional do que significar pensar, orientar-se no pensamento.

Contudo, em “O que é a filosofia?", todo o pensamento filosófico pressupõe uma Imagem do pensamento: justamente neste sentido, pensar sem imagens equivale a começar a filosofia sem imagens do pensamento, sem pressupostos. Deleuze e Guattari voltam a colocar a questão: "o que é a filosofia, o que é pensar. Pensar é um acontecimento, um acto criativo e não reflexivo ou representativo. Em ruptura com a Imagem tradicional e os seus

21 Deleuze, 2003a, p. 354 (Deleuze, 2000, pp. 438-439): "La théorie de la pensée est comme la peinture, elle a besoin de cette révolution qui la fait passer de la représentation à l'art abstrait; tel est l'objet d'une théorie de la pensée sans images."

22 Ibidem, p. 173. Para uma leitura da passagem do pensamento sem Imagem para a Imagem não representativa a partir do ponto de vista do carácter paradoxal atribuído ao conceito de Imagem do pensamento (em "O que é a filosofia?", Deleuze e Guattari identificam o plano de imanência com a Imagem do pensamento que é, em "Diferença e repetição”, um conceito criticado) cf. Silva, 2011, pp. 81-88.

23 Deleuze, 2003a, p. 173 (Deleuze, 2000, pp. 229-230): "Elle trouverait sa différence ou son vrai commencement, non pas dans une entente avec l'Image préphilosophique, mais dans une lutte rigoureuse contre l'Image, dénoncée comme nonphilosophie. Par là même, elle trouverait sa répétition authentique dans une pensée sans Image." 
próprios "mapas e imagens" 24 do que significa orientar-se no pensamento, procuram outros mapas e outras imagens: "Façam mapas e não fotografias nem desenhos." 25

Segundo esta abordagem, a filosofia, não sendo nem uma forma de conhecimento, nem de reconhecimento, é uma forma de pensamento conceptual ainda que o acto de pensar não lhe seja, no entanto, exclusivo: também a ciência e a arte pensam, ou seja, actualizam o pensamento nas funções de perceptos e afectos, por cada expressão do respectivo plano. O que é exclusivo do âmbito filosófico é a criação autopoiética de conceitos, a criação de conceitos que são expressão do pensamento e não representação de objectos exteriores. Pensar não é a representação de um objecto; pensar não é sequer uma relação entre um sujeito e um objecto. "O pensamento que nasce no pensamento, o acto de pensar originado na sua genitalidade, nem dado no inatismo, nem suposto na reminiscência, é o pensamento sem imagem", ${ }^{26}$ afirma demarcando o trabalho filosófico de qualquer possibilidade de ser confundido com o conhecimento: pensar conceptualmente (filosoficamente) não é conhecer nada, ou seja, filosofar não é reflectir sobre um determinado assunto, mas antes é a criação de conceitos, de conceitos que são auto-referenciais, fechados em si, e que, por sua vez, nascem do corte com o caos.

Contudo, em segundo lugar, e recuperando a citação que tivemos como ponto de partida - "O movimento automático faz surgir em nós um autômato espiritual, que, por sua vez, reage sobre ele" -, Deleuze destaca igualmente a importância da reacção que o autómato espiritual deve ter ao próprio automatismo cinematográfico que o gerou. Isto significa um novo circuito no qual o espírito já não segue passivamente as imagens, mas, antes pelo contrário, as imagens é que o forçam a pensar - trata-se de um noochoque. Deste modo, compreendemos que a primeira parte da frase citada de Deleuze - o automatismo do cinema cria o automatismo espiritual - seja tão importante como a final - a reacção ao automatismo espiritual -, a reacção que o espectador faz à Imagem-movimento (ou modelo clássico, dogmático do pensamento racionalista como representação). Tal como acontece na crise da Imagem-acção (caso de Alfred Hitchcock, por exemplo: a mente do filme é igual à mente do espectador), o espectador ganha uma dupla função activa: se, por um lado,

24 Martin, 2005 p. 15: "S'ouvre sur cette ligne extérieure toute une expérimentation qui reposera, à d'autres frais, la question de l'orientation : comment s'orienter dans la pensée ? Selon quelles cartes ? Selon quelles images?"

25 Deleuze e Guattari, 2001, p. 36: "Faites de cartes, et pas de photos ni des dessins."

26 Deleuze, 2003a, p. 217 (Deleuze, 2000, p. 281): "La pensée qui naît dans la pensée, l'acte de penser engendré dans sa génitalité, ni donné dans l'innéité ni supposé dans la réminiscence, est la pensée sans image." 
deve responder automaticamente às imagens que vê e ouve, numa relação de passividade (pelas percepções e afecções das imagens), por outro, destacase também a possibilidade de reacção pelo choque. A questão prende-se, ao contrário do que se julgaria, com a "afectividade e virtualidade" do cinema e a perda da subjectividade, isto é, com as duas maiores capacidades do cinema. Deste modo, Richard Rushton defende, consequentemente, um conceito de espectador em Deleuze sem que, no entanto, a subjectividade no presente desse espectador seja de modo algum considerada como pobre. ${ }^{27}$

Para Eisenstein, a montagem cinematográfica tem a função de associar a montagem das imagens à montagem das ideias com o objectivo de criar um Todo fechado significante. É por meio da montagem e da associação livre entre imagens ou planos que se constrói igualmente uma representação do tempo, representação indirecta mediante o controlo do movimento. Na montagem dialéctica de Eisenstein, e nas suas diversas modalidades, o choque é provocado pela oposição entre imagens: por exemplo, em "O Couraçado de Potemkin" ("Bronenosets Potyomkin", 1925), na cena da escadaria de Odessa, Eisenstein recorre à montagem rítmica que alia a duração de cada plano com o próprio movimento interno à cena, reforçando assim o conflito entre os dois movimentos, da montagem dos planos com o movimento compassado dos soldados que descem a escadaria. ${ }^{28} \mathrm{~A}$ uma práxis cinematográfica, corresponderá também, neste caso, uma práxis ideológica.

Todavia, para além deste primeiro movimento criado pela montagem, presente principalmente no cinema soviético (mas, de algum modo, extensível ao cinema da Imagem-movimento), de um movimento da Imagem para o pensamento (no qual o choque é provocado pela oposição das imagens que, por sua vez, obriga o pensamento a pensar o Todo - um Todo que não pode senão ser pensado), ${ }^{29}$ Deleuze fala igualmente do movimento inverso, do pensamento para a Imagem, isto é, de um movimento que cria figuras e metáforas: se a figura é criada a partir da emotividade do pensamento do espectador perante o conflito de imagens que percepciona, este choque sensorial leva, por

27 Rushton, 2008, p. 128, itálicos no original: "The empirical-bodily spectator responds automatically and mechanically - and at the same time viscerally and physiologically - to the image. Perhaps these might be called subjective images. But it is a very strange kind of subjectivity, a subjectivity with no background or backdrop, and a subjectivity that lives entirely in the present, as it were, reacting and responding only to filmic events as they happen. If these are subjective images, then they are certainly not images guided by a subject. Rather, they are the responses of a subject that has lost all subject hood, that has lost the traits of agency and self determination."

28 Sobre as diversas modalidades de montagem em Sergei Eisenstein (métrica, rítmica, tonal, harmónica, intelectual e vertical), cf. Ramos, 1981, pp. 21-27.

29 Deleuze, 1985, p. 203 (Deleuze, 2005, p. 197). 
sua vez, à criação de metáforas, ou seja, de clichés, a uma relação mediada pela representação.

É precisamente com este duplo movimento que podemos compreender que o autómato espiritual tenha dois momentos interpretativos distintos: se, por um lado, o autómato é activo, coincidindo com o movimento no pensamento (ou montagem das ideias) provocado pelo fora de si, por elementos que lhe são estrangeiros, por outro, ele também é passivo, como no caso concreto da montagem em Eisenstein, um movimento dialéctico, mediado pelas imagens que elaboram um conceito de espectador como um espírito entorpecido e guiado pelo cliché. O cinema deve interligar-se com a realidade íntima do cérebro, que não é o Todo mas a fissura (fêlure): ou seja, não é o pensamento do Todo, mas o dissociar, o deslocar, isto é, aquilo que é impensável dentro do próprio pensamento; o cinema não exalta o poder de tornar visível o pensamento mas revela o que é impensável no pensamento e de que modo o pensamento permanece "incompleto" ou em devir porque não há um Todo que pudesse ser pensado. A nova Imagem de cérebro proposta por Deleuze é, consequentemente, a da fissura entre imagens: "esta realidade íntima não é o Todo, pelo contrário, é uma fenda, uma fissura". ${ }^{30}$ Ou seja, o choque provocado entre imagens não define o poder de pensar mas antes a sua impotência em pensar, e é justamente esta inversão (que não se limita a uma mera negação, como veremos) que nos vai devolver a crença no mundo. ${ }^{31}$ Não está aqui presente o optimismo envolvido no inicial choque do pensamento e consequente pensamento do Todo tal como Eisenstein defendia, no sentido em que o choque servia à retórica marxista, à propaganda exposta na ligação lógica de imagens ainda que com ligações improváveis entre si.

O entre imagens é a nova Imagem do pensamento, Imagem do impensável, Imagem do todo. É o exterior ao pensamento, o impensável das imagens, que provoca o choque, que obriga a pensar o impensável. Deste modo, para Deleuze, o maior poder que o pensamento pode expressar não está no modelo representativo, enquanto modelo do conhecimento, mas no pensamento do impensável, quando este enfrenta a sua maior impotência. Deleuze passa assim da questão do próprio mecanismo cinematográfico, um aparelho que faz mover as imagens, para as imagens que se automovem: o movimento é o dado imediato das imagens.

30 Ibidem, p. 218: "Cette réalité intime n'est pas le Tout, c'est au contraire une fissure, une fêlure."

31 Para uma breve análise da relação entre o choque e o impensável nos filmes de Haneke, veja-se Viegas, 2010, pp 462-466. 


\section{Poder de pensar e automatismo}

A ruptura com o optimismo relativamente às consequências (sociais e políticas) do choque provocado pela montagem, tal como é divulgado por Sergei Eisenstein e pelas experiências de Kuleshov, aconteceu, segundo Deleuze, com Antonin Artaud, por meio da noção de "impotência". ${ }^{32}$ Deste modo, Deleuze aproximará a questão heideggeriana - o que dá mais que pensar é o facto de ainda não termos começado a pensar, ou seja, a própria impotência - ao pensamento de Artaud. Contudo, contrariando uma tendência em associar Artaud ao teatro e aos seus papéis enquanto actor de cinema, Deleuze, pelo contrário, vem evidenciar os seus escritos e críticas relativamente ao cinema identificando nele um "cinema da crueldade". Artaud, ainda numa primeira fase de optimismo perante a força (metafísica) dos fotogramas cinematográficos, dos fluxos que criam vibrações ${ }^{33}$ no pensamento, escreveu o argumento de "La coquille et le clergyman" (1928), realizado por Germaine Dulac, procurando criar imagens-pensamento deduzindo pensamento de outros pensamentos mas que superassem, subterrânea e inconscientemente, as próprias imagens-em-movimento. ${ }^{34}$ Ficou, no entanto, decepcionado com o seu resultado surrealista, com o apego ao elemento onírico como fuga ao despotismo do Logos e da consciência.

Ora, se Artaud se mostrou inicialmente admirado com as qualidades do cinema, com o ritmo, com a rapidez, com a quebra da continuidade narrativa, inclusive com o carácter ilusório e de distanciamento da realidade, ${ }^{35}$ vai, no entanto, repensar esse seu entusiasmo inicial. Na leitura que faz da relação entre o cinema e o cérebro - afirmando que o cinema comunica directamente com "a massa cinzenta do cérebro", 36 por "vibrações neurofisiológicas" e choques -, critica tanto o cinema experimental abstracto, como o cinema comercial de Hollywood: a ligação ou comunicação ocorre não na ideia de Todo (Eisenstein), mas na fissura. Ao poder de o cinema tornar visível a forma representativa do pensamento, opõe-se agora o poder de o cinema mostrar a

32 Artaud, 1982.

33 Ibidem, p. 5: "He creído al escribir el guion de La concha y el reverendo que el cine poseía un elemento propio, verdaderamente mágico, verdaderamente cinematográfico, y que nadie hasta entonces había pensado en decantar. Este elemento distinto de toda especie de representación ligada a las imágenes, participa de la vibración misma y del sentir inconsciente, profundo, del pensamiento. Se desprende subterráneamente de las imágenes y va surgiendo, no de su sentido lógico y articulado, sino de su unión, de su vibración y de su choque."

$34 \mathrm{Ibidem}$, p. 4: "La concha y el reverendo no cuenta una historia, sino que desarrolla una sucesión de estados del espíritu que se deducen los unos de los otros, como el pensamiento se deduce del pensamiento, sin que este pensamiento reproduzca la sucesión razonable de los hechos."

35 De Santiago, 1990, p. 152.

36 Artaud, 1982, p. 3: "El cine es un excitante notable. Actúa directamente sobre la materia gris del cerebro." 
impotência em se pensar, de dar espaço ao impensável, contra, de algum modo, o despotismo do Logos e da representação. Se Eisenstein afirma o Todo como essência do cinema, Artaud vem afirmar a impotência do pensamento como essência do cinema. O cinema é, neste sentido, falha, fissura, impossibilidade de criação ou reconstituição de um todo:37 "O mundo cinematográfico é um mundo morto, ilusório e parcelar". ${ }^{38} \mathrm{O}$ verdadeiro objecto-sujeito do cinema é a impotência do pensamento. Artaud e Espinosa representam assim posições opostas relativamente à Imagem do pensamento: se Espinosa exalta o poder do pensamento de auto-engendrar ideias pelas ideias, Artaud pretende ir além destas imagens-pensamento auto-engendradas e com ele compreendemos o que é a impotência de pensarmos. Deste modo, em "A Imagem-movimento", Deleuze afirma o correlato entre o automatismo técnico da máquina do cinema, através das imagens que se automovem, e o próprio automatismo do pensamento, correlato que, para Suzanne Hême De Lacotte, resolve o problema da origem de uma Imagem até então presa à criticada ideia de sujeito da Imagem dogmática do pensamento. ${ }^{39}$

Assim, a origem da Imagem é extrínseca; a Imagem é uma força vinda de fora do pensamento, logo, do próprio impensável sem ter origem num sujeito descrito como tendo a capacidade natural de pensar e de pensar a verdade. Ou seja, o cinema vem evidenciar isto mesmo - que o automatismo técnico é acompanhado pelo automatismo espiritual do espectador.

\section{Conclusão: 0 "Homem fascista" no cinema}

Porém, alguns perigos podem surgir desta passividade própria de uma arte mecânica e popular. ${ }^{40} \mathrm{Se}$, tal como acontece no cinema soviético, a massificação de uma arte é usada no seu carácter utilitário, servindo a uma "politização da arte", essa capacidade de reprodutibilidade técnica serviu também aos propósitos de um estado fascista de "esteticização da política", por exemplo,

37 Ibidem, pp. 12-13: "El cine, que no necesita de un lenguaje, de ninguna convención para ponernos en contacto con los objetos, no reemplaza, sin embargo, a la vida, se trata de pedazos de objetos, de jirones de realidad, de puzzles inacabados de cosas que el cine une entre sí para siempre. Y esto, piénsese lo que se piense, es muy importante, porque es preciso darse cuenta de que el cine nos presenta un mundo incompleto y de una vez por todas, y es agradable el hecho que de este mundo quede así fijado en su forma inacabada, porque si por un milagro los objetos así fotografiados, así estratificados en la pantalla, pudieran moverse, resulta difícil imaginar la imagen de la nada, el vacío en las apariencias que podrían llegar a crear."

38 Ibidem, p. 13: "El mundo cinematográfico es un mundo muerto, ilusorio y parcelado."

39 De Lacotte, 2006.

40 A passividade do espectador de cinema esteve na base do inicial afastamento entre cinema e filosofia e teoria da arte em grande parte fundado num pré-conceito relativamente a uma arte que se associava aos nickelodeons das feiras de diversão. Regressaremos ainda a esta crítica negativa. 
por meio do carácter "belo" da guerra, segundo a crítica elaborada por Walter Benjamim. ${ }^{41} \mathrm{O}$ entorpecimento próprio de um espírito mumificado - "O autômato espiritual tornou-se a Múmia, essa instância desmontada, paralisada, petrificada, congelada"42 -, corresponde a uma mente guiada pelo movimento das imagens e pelo cliché, pela mediocridade, que, no cinema, leva à ditadura do Homem fascista, do Homem verídico: o autómato espiritual tornou-se Múmia ou, pior, "o autómato espiritual tornou-se no homem fascista". ${ }^{43} \mathrm{Se}$ Benjamin refere que a massificação de uma arte reduz significativamente o seu carácter artístico, Elie Faure tentou, por seu lado, aproximar o automatismo material próprio da técnica cinematográfica ao automatismo intelectual do espectador assinalando que "[o] cinema é mais ou menos contemporâneo do fabrico em série, do motor, da radiofonia, da mecanização universal da produção. $^{44}$

De um modo subtil, o cinema, enquanto $a$ arte pública e popular característica do século XX, tornou possível a massificação de uma ideia de Homem fascista, tal como Deleuze a interpreta. Os perigos deste abuso são destacados por Deleuze citando, numa das suas aulas, um texto de Faure:

Aqui, é preciso pôr de lado o equívoco. Amigos sinceros do cinema viram nele apenas um admirável "instrumento de propaganda". Seja. Os fariseus da política, da arte, das letras e até das ciências encontrarão no cinema o mais fiel dos servidores até ao dia em que, por uma inversão mecânica dos papéis, será a vez de ele as dominar. ${ }^{45}$

Todavia, este uso é feito por "amigos sinceros do cinema", e não pelos seus inimigos ${ }^{46}$ - ou seja, esta mediocridade é quantitativa, é própria de uma arte industrial de contornos massivos cuja função propagandista não tem em consideração nenhuma ideologia em concreto. ${ }^{47}$ Contrariamente ao individualismo, no caso do cinema soviético, o cinema orienta os "ritmos colectivos",

41 Benjamin, 1992, pp. 111-113.

42 Deleuze, 1985, p. 217 (Deleuze, 2005, p. 201): “L'automate spirituel est devenu la Momie, cette instance démontée, paralysée, pétrifiée, gelée."

43 Ibidem, p. 215: "L'automate spirituel est devenu l'homme fasciste."

44 Faure, 1964, p. 48: "Le cinéma est à peu près contemporain de la fabrication en série, du moteur, de la radiophonie, de la mécanisation universelle de la production."

45 Ibidem, p. 51: "Ici, il faut écarter l'équivoque. Des amis sincères du cinéma n'ont vu en lui qu'un admirable «instrument de propagande». Soit. Les pharisiens de la politique, de l'art, des lettres, des sciences même, trouveront dans le cinéma le plus fidèle des serviteurs jusqu'au jour où, par une introversion mécanique des rôles, il les asservira à son tour. Ce n'est pas du dehors, et par «le sujet» en soi que nous demandons au cinéma de faire notre éducation." A aula de Gilles Deleuze em questão é datada de 30 de Outubro de 1984.

46 Tanto Deleuze como Benjamin identificam este "inimigo do cinema" como sendo Georges Duhamel: cf. Deleuze, 1985, p. 216 (Deleuze, 2005, p. 201) e Benjamin, 1992, p. 107.

47 Deleuze, 1985, p. 214 (Deleuze, 2005, p. 199). 
tomando a função de educador das massas mas também operando como instrumento de propaganda: no limite, instrumento para qualquer propaganda. É neste sentido que a força dos livros escritos por Deleuze sobre cinema e filosofia resulta, necessariamente, da mudança que operaram no âmbito do pensamento filosófico, da teoria do cinema e mesmo da cinefilia: como afirma Gregory Flaxman, parafraseando Foucault, "Cinema 1" e "Cinema 2" são "uma introdução a um pensamento não-fascista". ${ }^{48} \mathrm{O}$ noocinema surge como indicando os filmes que só podem ser pensados, que têm de ser pensados segundo uma nova lógica, segundo uma outra Imagem do pensamento. As imagens cinematográficas que nos fazem pensar não dizem respeito apenas ao conjunto de imagens que segue uma ideologia, um modelo despótico do que significa pensar, como acontece no primeiro regime de imagens, mas inclui também um campo de liberdade e de imprevisibilidade por meio do qual a Imagem escapa aos clichés dessa ideologia dominante.

Funcionando como verdadeiras cartografias do pensamento, estes filmes revelam o mapeamento dos movimentos do pensamento enquanto pura temporalidade, autopoiético e auto-referencial. Ou seja, a filosofia do cinema em Deleuze não é um pensamento do cinema mas uma cinematografia do pensamento. O novo cinema e os novos signos cinematográficos implicam, por isso, um novo pensamento.

\section{Referências}

ARTAUD, A. "El cine". Tradução de Antonio Eceiza. Madrid: Alianza, 1982. BENJAMIN, W. "Sobre arte, técnica, linguagem e política". Tradução de Maria Luz Moita et al. Lisboa: Relógio D’Água, 1992.

COADOU, F. “'L'automate spirituel'. Contribution à une étude sur la formation du concept de liberté chez Spinoza". Le Philosophoire, Nr. 17, pp. 187-201, 2002/2 [Online]. Disponível em: http://www.cairn.info/revue-le-philosophoire-2002-2page-187.htm (Acessado em 6 de abril de 2013).

DELEUZE, G. "Spinoza et le problème de l'expression". Paris: Les éditions de Minuit, 1968.

. “Cinéma 1: L'Image-mouvement". Paris: Les éditions de Minuit, 1983.

. "Cinéma 2: L'Image-temps". Paris: Les éditions de Minuit, 1985.

"Diferença e repetição". Tradução de Luiz Orlandi e Roberto Machado.

Lisboa: Relógio D’Água, 2000.

48 Flaxman, 2000, p. 3: "Ultimately, the cinema books should be read precisely because of their ambition, because they constitute, to twist a phrase of Foucault's, an 'introduction to non-fascist thinking'." 
DELEUZE, G. "Différence et répétition". Paris: Presses Universitaires de France, 2003a.

. "Le Juif Riche". In: Deux régimes de fous. Textes et entretiens 19751995. Édité par David Lapoujade. Paris: Les éditions de Minuit, 2003b. pp. 123-126. . “Conversações 1972-1990”. Lisboa: Fim de Século, 2003c.

. "Cinema 2: a imagem-tempo". Tradução de Eloisa de Araujo Ribeiro. São Paulo: Editora Brasiliense, 2005.

. "Cinema 1, a imagem-movimento". Tradução de Sousa Dias. Lisboa: Assírio e Alvim, 2009.

DELEUZE, G., GUATTARI, F. "O que é a filosofia?" Tradução de Margarida Barahona e António Guerreiro. Lisboa: Editorial Presença, 1992.

Éditions de Minuit, 2001.

. "Capitalisme et schizophrénie 2: Mille Plateaux". Paris: Les

. (1991). “Capitalisme et schizophrénie 3: Qu'est-ce que la philosophie?" Paris: Les éditions de Minuit, 2005.

DE GAINZA, M. "O 'privilégio do pensamento': um ensaio de interpretação". Cadernos Espinosanos, Vol. XVII, pp.71-79, 2007 [Online]. Disponível em: http:// www.fflch.usp.br/df/espinosanos/ARTIGOS/numero\%2017/mariana.pdf (Acessado em 6 de abril de 2013).

DE LACOTTE, S. H. "L'image de la pensée ou comment le cinéma nous aide à fonder de nouveaux présupposés philosophiques". Cinémas: Revue D'Études Cinématographiques/Cinémas: Journal of Film Studies, Vol. 16, Nr. 2-3, pp. 54-72, 2006 [Online]. Disponível em: http://id.erudit.org/iderudit/014615ar (Acessado em: 12 de janeiro de 2012).

DE SANTIAGO, C. "Antonin Artaud: la relación de sus teorías teatrales con el cine". 1616: Anuario de la Sociedad Española de Literatura General y Comparada, Vol. VIII, pp. 151-158, 1990 [Online]. Disponível em: http://descargas.cervantesvirtual. com/servlet/SirveObras/57915842005572617400080/018590.pdf?incr=1 (Acessado em 12 de janeiro de 2012).

ESPINOSA. "Euvres complètes". Paris: Gallimard, 1954. . "EEuvres 1: Traité de la réforme de l'Entendement". Paris: Garnier-

Flammarion, 1964. . "Tratado sobre a Reforma do Entendimento". Tradução de António Borges Coelho. Lisboa: Livros Horizonte, 1971.

EPSTEIN, J. “L'intelligence d'une machine”. Paris: Éditions Jacques Melot, 1946. EZCURDIA, J. "O Autômato Espiritual na filosofia de Espinosa. Implicações de uma Ontologia Imanentista no plano do conhecimento científico". Tradução de Homero Santiago. Cadernos Espinosanos, Vol. XXIV, pp. 11-33, 2001 [Online]. Disponível em: http://www.fflch.usp.br/df/espinosanos/ARTIGOS/numero\%2024/jose.pdf (Acessado em 06 de abril de 2013).

FAURE, E. "Fonction du cinéma: de la cinéplastique à son destin social". Paris: Gonthier, 1964. 
FLAXMAN, G. (ed.). "The brain is the screen: Deleuze and the philosophy of cinema". Minneapolis: University of Minnesota Press, 2000.

MACHEREY, P. "The encounter with Spinoza". In: P. Patton (ed.). Deleuze: a critical reader. Oxford: Blackwell Publishing, 1996. pp. 139-161.

MARTIN, J.-C. "La Philosophie de Gilles Deleuze”. Paris: Éditions Payot \& Rivages, 2005.

RAMOS, J. L. "Sergei Eisenstein". Lisboa: Livros Horizonte, 1981.

RUSHTON, R. "Passions and Actions: Deleuze's Cinematographic". Cogito. Deleuze Studies, Vol. 2, Nr. 2, pp. 121-139, 2008.

SILVA, C. V. "Pintura e cinema em Deleuze: do pensamento sem imagem às imagens não representativas." Revista Artefilosofia, Nr. 10, pp.81-88, 2011 [Online]. Disponível em: http://www.raf.ifac.ufop.br/pdf/artefilosofia_10/Pag_81_Pintura_E_Cinema.pdf (Acessado em 06 de abril de 2013).

VIEGAS, S. "Filosofia e cinema: os filmes de Michael Haneke". AVANCA|CINEMA, Tomo I, Edições Cine-Clube de Avanca, pp. 462-466, 2010. 